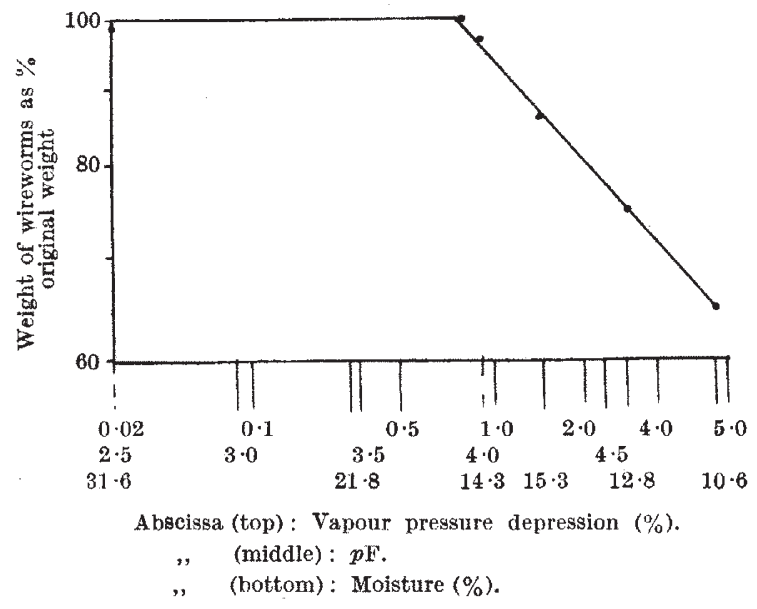

water is lost chiefly through the cuticle, there being little or no excretion. In the drier soils the vapour pressure depression is due mainly to the 'suction' of the soil moisture, that is, to the fact that the water retained in the soil pores has a pressure less than that of atmospheric pressure. A suction of eight atmospheres produces a depression of $0 \cdot 6$ per cent. Adopting the scale proposed by Schofield, in which $p F$ represents the logarithm of the height in centimetres of a column of water corresponding to the suction, we can say that the wireworms were in moisture equilibrium with the soil at $p \mathbf{F} 3 \cdot 9$.

Further experiments with other soils have confirmed that the rate of loss of water is governed by the 'suction' and not by the moisture content of the soil.

\begin{tabular}{|c|c|c|c|}
\hline \multicolumn{2}{|l|}{ Type of soil } & $\begin{array}{c}\% \text { Moisture content } \\
\text { at } p E^{5} \cdot 0\end{array}$ & $\begin{array}{l}\text { Weight of wire- } \\
\text { worms after } 5 \text { week } \\
\text { as } \% \text { original wt. }\end{array}$ \\
\hline Woburn Sandy & $\therefore$ & 4.03 & $56 \cdot 7$ \\
\hline Rothamsted allotment & $\cdots$ & $7 \cdot 52$ & $55 \cdot 9$ \\
\hline Rich loam $\quad$.. & .. & $10 \cdot 38$ & $56 \cdot 9$ \\
\hline & & $\begin{array}{r}p \text { F at a moisture } \\
\text { content of } 10 \cdot 38\end{array}$ & * \\
\hline Rothamsted allotment & . & $4 \cdot 1$ & $86 \cdot 9$ \\
\hline Woburn Sandy .. & . & $3 \cdot 6$ & $102 \cdot 2$ \\
\hline
\end{tabular}

It is quite clear that the $p \mathbf{F}$ scale suitably expresses the dryness or wetness of a soil in relation to the loss of weight of wireworms, and should prove of value in studies of a similar kind.

A. C. Evans.

Rothamsted Experimental Station, Harpenden, Herts. May 28.

1 Subklew, w., Z. morph. u Oekol. Tiere, 28, 184 (1934).

Woodworth, C. F., J. Agric. Res., 57, 229 (1989).

- Schofleld, R. K., and Botelho da Costa, J. V., J. Agric. Sci, 28, 644 (1938).

'Davidgon, A. I. C., and Schofeld, R. K., J. Agric. Sci., 32, 413 (1942).

\section{Effect of p-Aminobenzoic Acid on Defective Cultures of Bacteria}

IT has been shown by C. E. Cahn-Bronner ${ }^{1}$ that the phenomenon of bacterial zones can be produced by partial starvation.

Some aerobic bacteria and yeasts were found to grow in a layer under the surface of the fluid culture; with increasing starvation such organisms were more sensitive to oxygen, which had a mildly bacteriostatic effect on them.

This phenomenon of sensitivity to oxygen is due to lack of easily oxidizable substances, mainly carbohydrates, in the medium (acting as oxygen acceptors). This type of growth is also observed in cultures of $B$. subtilis grown on semi-synthetic medium containing hydrolysed casein. Strains of $B$. subtilis grown on digest broth produce a normal growth after 24 hours in the form of diffuse turbidity and a pellicle on the surface of the medium, whereas on the synthetic medium described by Loonard and Holme ${ }^{2}$, with 0.1 per cent acid-hydrolysed casein instead of proteose peptone, there was weak growth in the form of slight turbidity in the deeper layers of the culture after 24 hours but no pellicle on the surface. In absence of hydrolysed casein, growth was still less noticeable, and it was several days before the turbidity was sufficient to be estimated. Surface growth with normal pellicle formation occurred when $p$-aminobenzoic acid was added to the medium in a concentration of $1: 2,500$ to $1: 1,100,000$. In absence of hydrolysed casein, however, surface growth did not take place within 24 hours.

The addition of 4 per cent human serum to the synthetic medium had the same effect as the addition of $p$-aminobenzoic acid (and hydrolysed casein). Addition of sulphonamide compounds having antibacterial properties in dilutions up to $1: 100,000$ inhibited the surface growth-promoting effect of $p$-aminobenzoic acid in the synthetic medium. This probably explains Mandelbaum's observation on bacterial asthenia ${ }^{2}$.

Another example of defective growth under the influence of sulphonamide drugs is shown by cultures of Ps. pyocyanea in synthetic medium, in which not only is there scanty pellicle formation but also a deficiency of pigment formation over a period of 24 hours when sulphonamides are added in dilutions from $1: 5,000$ to $1: 50,000$. p-Aminobenzoic acid antagonized the adverse effect of the compounds in dilutions up to $1: 50,000$.

\section{J. UNGAR.}

Department of Experimental Medicine, Glaxo Laboratories, Ltd., Greenford, Middlesex. June 9.

\footnotetext{
1 Proc. Soc. Biol, and Med, 45, 454 (1940).

'J. Immun., 29, No. 3, 209 (1935).

3 NATURE, 147, 266 (1941).
}

\section{Archæology as a Science}

The antithesis between history and science as central disciplines in "education for citizenship" can be resolved by making history more archæological and recognizing that archæology is a science. Mr. Hansel's just complaint" that "the humanities specialize in inhumanity -instruction in the accumulated evil, strife and intrigue of the ages" does not apply to prehistory, which is exclusively archæological-and archæology does not stop short when written history begins. For archæology, evil is not cumulative-one might be tempted to say, is what is not cumulative. In the arch oological record (in a 